\title{
Seizures as an Adverse Event of Cellular Therapy in Pediatric Neurological Disorders and its Prevention
}

\author{
Alok Sharma ${ }^{1}$, Hemangi Sane ${ }^{2}$, Amruta Paranjape $^{2^{*}}$, Nandini Gokulchandran ${ }^{1}$, Mansi Takle ${ }^{3}$ and Prerna Badhe \\ ${ }^{1}$ Department of Medical Services and Clinical research, NeuroGen Brain and Spine Institute, Chembur, Mumbai, India \\ ${ }^{2}$ Department of Research and development, NeuroGen Brain and Spine Institute, Chembur, Mumbai, India \\ ${ }^{3}$ Department of Neurorehabilitation, NeuroGen Brain and Spine Institute, Chembur, Mumbai, India
}

*Corresponding author: Amruta Paranjape, NeuroGen Brain and Spine Institute, Surana Sethia Hospital, Suman Nagar, Sion-Trombay road, Chembur (East), Mumbai, India, Tel: + 919819430984; E-mail: amruta.paranjape@live.co.0000uk

Rec date: Apr 17, 2014, Acc date: Jun 03, 2014, Pub date: Jun 06, 2014

Copyright: (C) 2014 Sharma A, et al. This is an open-access article distributed under the terms of the Creative Commons Attribution License, which permits unrestricted use, distribution, and reproduction in any medium, provided the original author and source are credited.

\begin{abstract}
This study reports seizures as an adverse event (AE) in children with neurological diseases treated with autologous bone marrow mononuclear cells (BMMNCs) intrathecal transplantation. It also assesses the effectiveness of antiepileptic prophylactic regimen to reduce the incidence of seizures as an AE. Seizures were considered as an $\mathrm{AE}$ if there were increased pre-existing seizures or new onset seizures. In part I; seizures as an $A E$ was analyzed in detail. Seizures occurred as an AE in 8/131 (6\%) in part I. Out of these 8, one patient's EEG was not available, but showed increased preexisting seizures and 7 had a pre-existing epileptogenic focus on EEG. Out of these 7, 3 developed new onset seizures and 4 had increased pre-existing seizures. Based on this analysis an antiepileptic prophylactic regimen was designed. In Part II effect of this regimen was studied and a significant decrease in the incidence of seizures as an AE was observed along with no new onset seizures. Though small proportions of patients show seizures as an $\mathrm{AE}$ of cellular therapy, it definitely requires attention and is preventable. Pre-existing epileptogenic focus is an independent predictor for seizures as an AE. Future clinical trials of cellular therapy in pediatric population may consider these findings.
\end{abstract}

Keywords: Stem cells; Cellular therapy; Adverse event; Epilepsy; Seizures; Autologous bone marrow Mononuclear cells; Pediatric neurological diseases

\section{Introduction}

Recent advances in the cellular therapy have led to a neurorestorative approach for the treatment of pediatric neurological diseases [1-3] Cellular therapy is being widely explored for the treatment of various incurable neurological disorders [2,4-7]. There are numerous ongoing clinical trials worldwide studying the therapeutic potential of cellular therapy. But it is also imperative to study the adverse events associated with cellular therapy. There have been reports of adverse events like teratoma formation [8] with the use of embryonic stem cells and immunogenic response with umbilical cord stem cells [9]. Although autologous bone marrow mononuclear cells (BMMNCs) transplantation studies have shown relative safety and efficacy for pediatric neurological disorders [2,5] there have been reports of seizures as an adverse event [5]. One study of allogenic bone marrow transplantation in children with leukemia has reported seizures during the first three months follow-up. [10]. In a case series of adult stroke patients, autologous BMMNCs intrathecal transplantation have shown new onset seizures [11].

Seizure has been commonly identified as a co-morbid condition in autism, attention deficit hyperactivity syndrome, rett's syndrome, mental retardation, cerebral palsy and cerebellar ataxia $[12,13]$. Therefore, occurrence of seizure after cell therapy needs to be interpreted carefully as an adverse event and studied in depth.
In this article, we report seizures as an adverse event (AE) of autologous BMMNCs intrathecal transplantation in pediatric neurological disorders (autism, attention deficit hyperactivity syndrome, rett's syndrome, mental retardation, cerebral palsy and cerebellar ataxia).

\section{Reporting of Seizures as an AE (Part I)}

\section{Materials and Methods}

\section{Study design, participant inclusion criteria}

A retrospective analysis of seizures as an adverse event of autologous BMMNCs intrathecal transplantation was conducted. Seizure was considered as an adverse event if there was increased preexisting seizures (frequency or intensity) or development of new onset seizures.

Inclusion criteria: Children and adolescents up to the age of 18 who were diagnosed with autism, attention deficit hyperactivity syndrome, rett's syndrome, mental retardation, cerebral palsy or cerebellar ataxia and received treatment with autologous BMMNCs intrathecal transplantation.

Detailed information about history of the seizures was gathered over three years and two months, history of treatment with antiepileptic drugs and electroencephalograph (EEG) findings was compiled and then analyzed. 
Citation: Sharma A, Sane H, Paranjape A, Gokulchandran N, Takle M, et al. (2014) Seizures as an Adverse Event of Cellular Therapy in Pediatric Neurological Disorders and its Prevention. J Neurol Disord 2: 164. doi:10.4172/2329-6895.1000164

Page 2 of 8

\section{Intervention}

The intervention consisted of autologous BMMNCs intrathecal transplantation. Revised World Medical Association Helsinki Declaration for Ethical Principles for medical research involving human subjects provided the rationale for cellular transplantation [14]. A thorough pre-transplantation assessment was conducted including necessary investigations. Granulocyte Colony Stimulating Factor (GCSF) was administered 48 hours and 24 hours before the harvest and transplantation of BMMNCs to enhance the mobilization [15]. Bone marrow was aspirated by a standard procedure. Mononuclear cells were isolated by density gradient method. Viability and CD34+ count was performed. Intrathecal transplantation of the autologous bone marrow mononuclear cells was done by a standard lumbar puncture procedure (the procedure has been described in further detail in the previous publication [5]). Patients were monitored for any immediate in-hospital AEs for one week post transplantation and late AEs for at least six months. Patients also underwent multidisciplinary rehabilitation for six months as a home program.

\section{Data synthesis and analysis}

We gathered the information about increased pre-existing seizures or development of new onset seizures from patients and records. The data was also reviewed to ascertain the time to event from treatment onset for each patient. Those patients who did not come for a follow up, were contacted telephonically and detailed information about the occurrence of seizures post cellular transplantation was noted.

The information was segregated into various groups. Three groups were made. One group consisted of patients without pre-existing epileptogenic focus on EEG. Second group consisted of patients with pre-existing epileptogenic focus on EEG. Third group consisted of patients with no EEG information available. All the groups were further divided based on the presence or absence of history of seizures. The percentage incidence of seizures as an AE post cellular therapy was calculated and compared for all these groups (Table 1 and Figure 2). The comparison of the incidence was to identify the population with a higher risk of developing seizures as AE post cellular therapy.

\section{Results}

A total of 131 patients met the inclusion criteria. Information gathered over three years and two months was analyzed. For demographic and diagnoses distribution (Table 2). Out of these 131 patients; 8 (6\%) had seizures as an AE post BMMNCs transplantation (Figure 1A and Table 1). None of these patients were on any medications that are known to lower seizure threshold. Characteristics of these 8 patients are summarized in Table 3 .

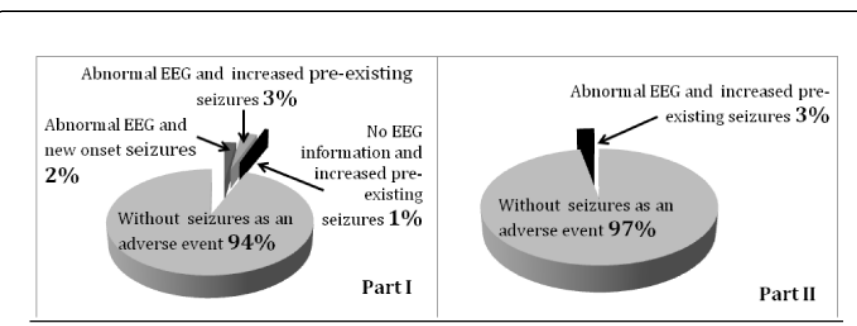

Figure 1A: Diagram depicting reduction of seizures as an adverse event in part II where patients were given antiepileptic prophylactic regimen, Comparison between all the patients in Part I and part II. ${ }^{*}$ There were no new onset seizures in Part II

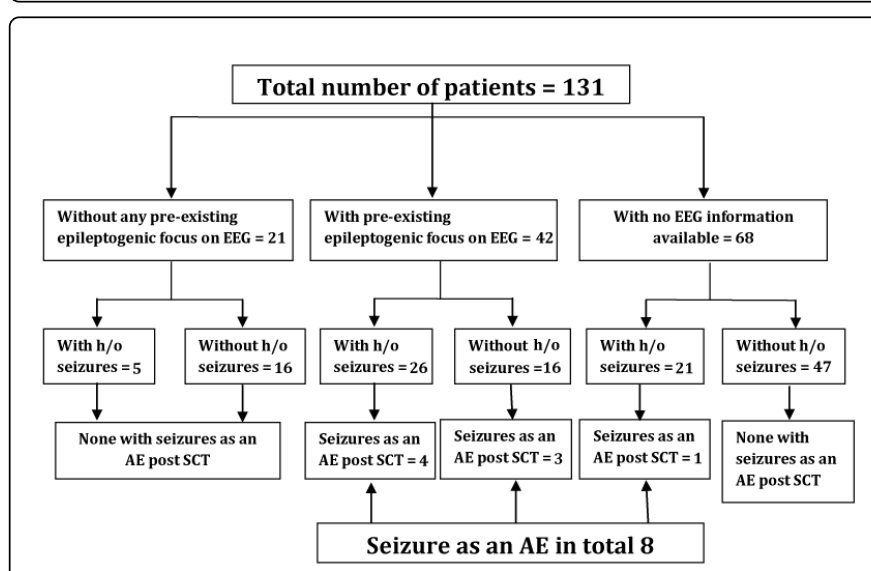

Figure 2: Distribution of patients who did not undergo prophylactic antiepileptic regimen

\begin{tabular}{|l|l|l|l|l|}
\hline \multirow{2}{*}{ Patient Characteristics * } & \multicolumn{2}{|l|}{ Normal EEG } & Abnormal EEG \\
\cline { 2 - 5 } & Total number of patients & $\begin{array}{l}\text { Number of patients with } \\
\text { seizures as a side effect post } \\
\text { BMMNCs transplantation }\end{array}$ & Total Number of patients & $\begin{array}{l}\text { Number of patients with seizures } \\
\text { as a side effect post BMMNCs } \\
\text { transplantation }\end{array}$ \\
\hline $\begin{array}{l}\text { Patients with the history of seizures } \\
\text { and antiepileptic medication }\end{array}$ & 1 & 0 & 15 & 4 \\
\hline $\begin{array}{l}\text { Patients with history of seizures } \\
\text { without any antiepileptic medication }\end{array}$ & 4 & 0 & 11 & 0 \\
\hline $\begin{array}{l}\text { Patients without any history of } \\
\text { seizures but on antiepileptic } \\
\text { medication }\end{array}$ & 0 & 0 & 2 & 0 \\
\hline
\end{tabular}


Citation: Sharma A, Sane H, Paranjape A, Gokulchandran N, Takle M, et al. (2014) Seizures as an Adverse Event of Cellular Therapy in Pediatric Neurological Disorders and its Prevention. J Neurol Disord 2: 164. doi:10.4172/2329-6895.1000164

Page 3 of 8

\begin{tabular}{|l|l|l|l|l|}
\hline $\begin{array}{l}\text { Patients without any history of } \\
\text { seizures or antiepileptic medication }\end{array}$ & 16 & 14 & 3 \\
\hline
\end{tabular}

Table 1: Distribution of patients who did not undergo prophylactic antiepileptic regimen; according to EEG findings, history of seizures and antiepileptic medication

*There was one patient; whose EEG status was not known, with a medication; that showed increased frequency and intensity of seizures history of one episode of febrile seizures and no history of antiepileptic post stem cell therapy.

\begin{tabular}{|c|c|c|c|}
\hline \multicolumn{2}{|c|}{ Demographic characteristics of patients } & $\begin{array}{l}\text { Number of patients who did not undergo any } \\
\text { antiepileptic prophylaxis (Total number of } \\
\text { patients }=131 \text {, Mean age }=9.5 \text { years) }\end{array}$ & $\begin{array}{l}\text { Number of patients who underwent a antiepileptic } \\
\text { prophylactic regimen ( total number of } \\
\text { patients }=67 \text {, Mean age }=9 \text { years) }\end{array}$ \\
\hline \multirow{2}{*}{ Gender distribution } & Males & 90 & 51 \\
\hline & Females & 41 & 16 \\
\hline \multirow{6}{*}{$\begin{array}{l}\text { Distribution according to } \\
\text { the diagnosis }\end{array}$} & Autism & 50 & 36 \\
\hline & Cerebral palsy & 64 & 22 \\
\hline & Cerebellar ataxia & 7 & 1 \\
\hline & Mental retardation & 7 & 5 \\
\hline & $\begin{array}{l}\text { Attention deficit } \\
\text { hyperactivity disorder }\end{array}$ & 0 & 3 \\
\hline & Rett's syndrome & 3 & 0 \\
\hline
\end{tabular}

Table 2: Population distribution by gender and diagnosis

\begin{tabular}{|c|c|c|c|c|c|c|c|}
\hline & $\begin{array}{lr}\text { Type ref } \\
\text { seizures (pre } \\
\text { and post } \\
\text { intervention) }\end{array}$ & $\begin{array}{lr}\text { Number of } & \text { seizure } \\
\text { episodes post } \\
\text { intervention }\end{array}$ & $\begin{array}{l}\text { Duration } \\
\text { between the } \\
\text { cellular } \\
\text { therapy and } \\
\text { first seizure } \\
\text { episode }\end{array}$ & $\begin{array}{lr}\text { Duration } & \text { over } \\
\text { seizure } & \text { episodes } \\
\text { recurred } & \end{array}$ & $\begin{array}{l}\text { Medication used } \\
\text { for seizure control }\end{array}$ & $\begin{array}{l}\text { Seizure related } \\
\text { complications }\end{array}$ & $\begin{array}{l}\text { Effect of seizures on clinical } \\
\text { improvement }\end{array}$ \\
\hline Patient I & $\begin{array}{l}\text { Pre- GTC } \\
\text { Post- GTC }\end{array}$ & One & Six months & No Recurrence & Midazolam & None & $\begin{array}{l}\text { There was no deterioration in } \\
\text { the baseline and the marked } \\
\text { clinical improvement was } \\
\text { maintained }\end{array}$ \\
\hline Patient II & $\begin{array}{l}\text { Pre - Febrile } \\
\text { seizures } \\
\text { Post - GTC }\end{array}$ & Multiple & Four months & Ten months & \begin{tabular}{lr}
\multicolumn{2}{l}{ Sodium Valproate } \\
dose was doubled. \\
Clobazam was \\
discontinued & and \\
Lamotrigine & was \\
added
\end{tabular} & None & $\begin{array}{l}\text { There was no deterioration in } \\
\text { the baseline and the marked } \\
\text { clinical improvement was } \\
\text { maintained }\end{array}$ \\
\hline Patient III & $\begin{array}{l}\text { Pre- No } \\
\text { seizures } \\
\text { Post- GTC }\end{array}$ & Two & Three months & Three months & Sodium Valproate & None & $\begin{array}{l}\text { There was no deterioration in } \\
\text { the baseline and the marked } \\
\text { clinical improvement was } \\
\text { maintained }\end{array}$ \\
\hline Patient IV & $\begin{array}{l}\text { Pre - GTC } \\
\text { Post - GTC }\end{array}$ & Multiple & Two weeks & Two months & $\begin{array}{ll}\begin{array}{l}\text { Valproate } \\
\text { increased, }\end{array} & \\
\text { Lamitec, } & \text { ACTH } \\
\text { injections } & \end{array}$ & None & $\begin{array}{l}\text { There was no deterioration in } \\
\text { the baseline and the marked } \\
\text { clinical improvement was } \\
\text { maintained }\end{array}$ \\
\hline Patient V & $\begin{array}{ll}\text { Pre } & - \\
\text { Myoclonic } & \\
\text { Post } & - \\
\text { Myoclonic } & \end{array}$ & Multiple & One month & $\begin{array}{l}\text { Three months } \\
\text { (Frequency reduced } \\
\text { to the same as } \\
\text { before SCT) }\end{array}$ & $\begin{array}{l}\text { Lamitec, } \\
\text { Clobazam, } \\
\text { valproate }\end{array}$ & None & $\begin{array}{l}\text { There was no deterioration in } \\
\text { the baseline and the marked } \\
\text { clinical improvement was } \\
\text { maintained }\end{array}$ \\
\hline Patient VI & $\begin{array}{l}\text { Pre } \\
\text { Myoclonic }\end{array}$ & Multiple & Two months & $\begin{array}{l}\text { Six months } \\
\text { medical }\end{array} \begin{array}{c}\text { care, }\end{array}$ & $\begin{array}{l}\text { Valproate dosage } \\
\text { increased, }\end{array}$ & None & $\begin{array}{l}\text { There was no deterioration in } \\
\text { the baseline and the marked }\end{array}$ \\
\hline
\end{tabular}


Citation: Sharma A, Sane H, Paranjape A, Gokulchandran N, Takle M, et al. (2014) Seizures as an Adverse Event of Cellular Therapy in Pediatric Neurological Disorders and its Prevention. J Neurol Disord 2: 164. doi:10.4172/2329-6895.1000164

Page 4 of 8

\begin{tabular}{|l|l|l|l|l|l|l|l|}
\hline & $\begin{array}{l}\text { Post } \\
\text { Myoclonic }\end{array}$ & & $\begin{array}{l}\text { frequency was } \\
\text { higher than before till } \\
\text { the end of the follow } \\
\text { up period) }\end{array}$ & $\begin{array}{l}\text { Clobazam and } \\
\text { Levetiracetam } \\
\text { dosage same as } \\
\text { before }\end{array}$ & $\begin{array}{l}\text { clinical improvement was } \\
\text { maintained }\end{array}$ \\
\hline Patient VII & $\begin{array}{l}\text { Pre _ No } \\
\text { seizures } \\
\text { Post - GTC }\end{array}$ & Multiple & One month & Three months & $\begin{array}{l}\text { Antiepileptic } \\
\text { medication }\end{array}$ & None & $\begin{array}{l}\text { There was no deterioration in } \\
\text { the baseline and the marked } \\
\text { clinical improvement was } \\
\text { maintained }\end{array}$ \\
\hline Patient VIII & $\begin{array}{l}\text { Pre - No } \\
\text { seizures } \\
\text { Post - GTC }\end{array}$ & Multiple & One week & Eighteen months & $\begin{array}{l}\text { Antiepileptic } \\
\text { medication }\end{array}$ & None & $\begin{array}{l}\text { There was no deterioration in } \\
\text { the baseline and the marked } \\
\text { clinical improvement was } \\
\text { maintained }\end{array}$ \\
\hline
\end{tabular}

Table 3: Details of Eight patients who had seizures as an adverse event post cellular therapy

Out of these 131 patients 42 had a pre-existing epileptogenic focus on EEG. 7 out of 42 patients (17\%), showed presence of seizures as an AE (Figure 1B and Table 1). 4 (57\%) out of these 7 patients had preexisting history of seizures and were compliant with their antiepileptic medications. $3(43 \%)$ out of 7 developed new onset seizures post intervention.

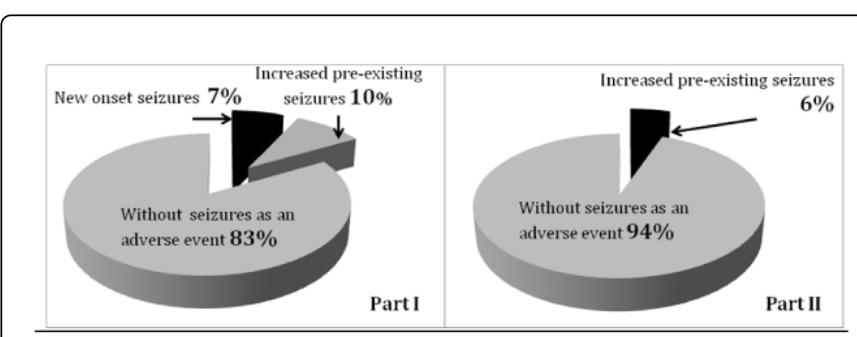

Figure 1B: Comparison between patients with pre-existing epileptogenic focus in Part I and part II

${ }^{*}$ There were no new onset seizures in Part II

Out of 131 patients 21 had normal EEG. None of these patients developed seizures as an $\mathrm{AE}$ post intervention (Table 1).

Out of 131 patients 68 patients did not have any EEG information available (Table 1). Out of these 68 , there was 1 patient who had seizures as an AE post intervention. This patient had experienced only one episode of febrile seizures in childhood with no recurrence and no antiepileptic medication.

Based on the analysis of part I, prophylactic antiepileptic regimen was devised (Table 4 and Figure 3 ) and Part II was conducted.

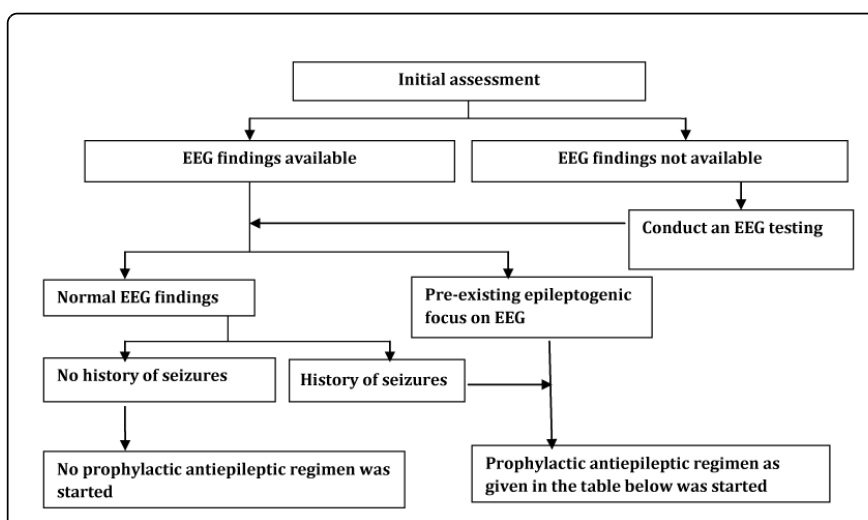

Figure 3: Assessment of patients for antiepileptic prophylactic regimen

\begin{tabular}{|c|c|c|c|}
\hline \multicolumn{4}{|c|}{ Antiepileptic prophylactic regimen } \\
\hline Criteria & & $\begin{array}{l}\text { Patients with pre-existing } \\
\text { epileptogenic focus on EEG } \\
\text { (Abnormal EEG) }\end{array}$ & $\begin{array}{l}\text { Patients without pre-existing epileptogenic focus on EEG } \\
\text { (Normal EEG) }\end{array}$ \\
\hline \multirow[t]{2}{*}{ 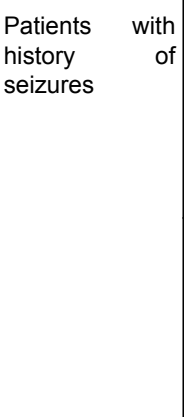 } & $\begin{array}{l}\text { Patients already } \\
\text { taking antiepileptic } \\
\text { medication }\end{array}$ & $\begin{array}{l}\text { On the day of transplantation } \\
\text { Previous medication with same dosage, IV, twice a day at an } \\
\text { interval of } 12 \text { hours } \\
\text { From the next day of transplantation } \\
\text { Previous medication with the same dosage as before, oral }\end{array}$ & $\begin{array}{l}\text { On the day of transplantation } \\
\text { Previous medication with same dosage, IV, twice a day at } \\
\text { an interval of } 12 \text { hours } \\
\text { From the next day of transplantation } \\
\text { Previous medication with the same dosage as before, oral }\end{array}$ \\
\hline & $\begin{array}{l}\text { Patients not taking } \\
\text { any antiepileptic } \\
\text { medication }\end{array}$ & $\begin{array}{l}\text { On the day of transplantation } \\
\text { Levetiracetam } 10 \mathrm{mg} / \mathrm{kg} \text { body weight, IV, twice a day at an } \\
\text { interval of } 12 \text { hours } \\
\text { From the next day of transplantation } \\
\text { Levetiracetam } 10 \mathrm{mg} / \mathrm{kg} \text { body weight, oral for } 3 \text { months }\end{array}$ & $\begin{array}{l}\text { On the day of transplantation } \\
\text { Levetiracetam } 10 \mathrm{mg} / \mathrm{kg} \text { body weight, IV, twice a day at an } \\
\text { interval of } 12 \text { hours } \\
\text { From the next day of transplantation } \\
\text { Levetiracetam } 10 \mathrm{mg} / \mathrm{kg} \text { body weight, oral for } 3 \text { months }\end{array}$ \\
\hline
\end{tabular}


Citation: Sharma A, Sane H, Paranjape A, Gokulchandran N, Takle M, et al. (2014) Seizures as an Adverse Event of Cellular Therapy in Pediatric Neurological Disorders and its Prevention. J Neurol Disord 2: 164. doi:10.4172/2329-6895.1000164

Page 5 of 8

\begin{tabular}{|c|c|c|c|}
\hline $\begin{array}{l}\text { Patients without } \\
\text { history of } \\
\text { seizures }\end{array}$ & $\begin{array}{l}\text { Patients not taking } \\
\text { any antiepileptic } \\
\text { medication }\end{array}$ & $\begin{array}{l}\text { On the day of transplantation } \\
\text { Levetiracetam } 10 \mathrm{mg} / \mathrm{kg} \text { body weight, IV, twice a day at an } \\
\text { interval of } 12 \text { hours } \\
\text { From the next day of transplantation } \\
\text { Levetiracetam } 10 \mathrm{mg} / \mathrm{kg} \text { body weight, oral for } 3 \text { months }\end{array}$ & Antiepileptic prophylaxis was not given to any patient \\
\hline
\end{tabular}

Table 4: Assessment of patients for antiepileptic prophylactic regimen in Part II and antiepileptic prophylactic regimen

\section{Prophylaxis for Seizures as an AE (Part II)}

\section{Materials and Methods}

Part II analyzed the effect of prophylactic antiepileptic regimen on seizures as an AE of autologous BMMNCs intrathecal transplantation. Patients of identical age group and diagnosis as in part I and who were given prophylactic antiepileptic regimen, were included for analysis.

Procedure for BMMNCs transplantation and multidisciplinary rehabilitation was identical for all patients as that in Part I. In addition, they underwent a prophylactic regimen of antiepileptic drugs based on the previous history of seizures or treatment with any antiepileptic medication and EEG findings prior to transplantation (EEG was considered abnormal only in presence of epileptogenic focus). This prophylactic regimen was devised based on the analysis of the data gathered in Part I. Table 4 describes Prophylactic regimen.

Prophylaxis was started on the day of cell transplantation and continued for 3 months. After three months, based on the follow up findings, patients were advised regarding further continuation of the medication. Patients with no seizure episode for three months were advised to discontinue the prophylactic medication. In the event of increased pre-existing seizures or new onset seizures patients were advised to contact us immediately for antiepileptic medicine dosage adjustment.

Patients were advised to come for a follow up at three months and six months post cellular therapy. Those patients who did not come for a follow up were contacted telephonically. During each follow up a detailed assessment was carried out to identify seizures as an AE and the side effects of prophylactic medication.
The patients were segregated into two groups. One group consisted of patients without a pre-existing epileptogenic focus on EEG. Second group consisted of patients with a pre-existing epileptogenic focus on EEG. These groups were further divided into two groups each based on presence or absence of history of seizures (Table 5 and Figure 4). The percentage incidence of seizures as an AE post cellular therapy was calculated separately for each group. The results were then compared with the results of Part I, to find out the effect of prophylaxis.

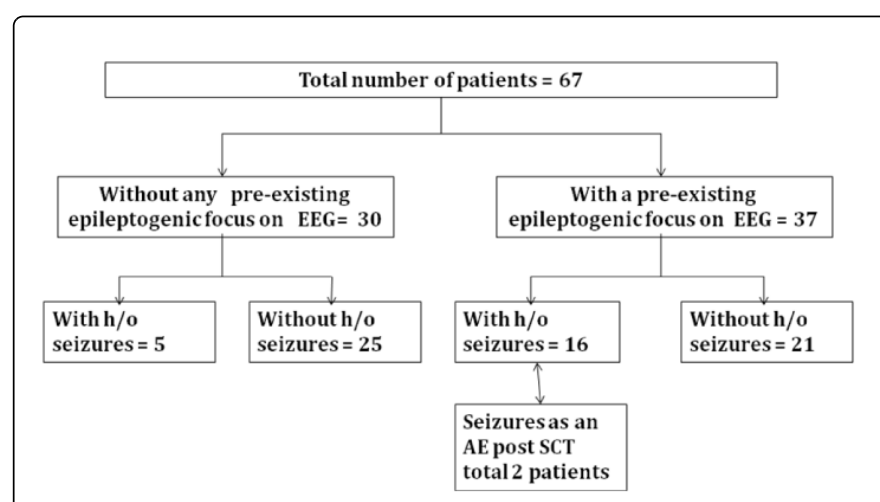

Figure 4: Distribution of patients who underwent prophylactic antiepileptic regimen

\begin{tabular}{|l|l|l|l|l|}
\hline \multirow{2}{*}{ Patient Characteristics } & \multicolumn{2}{|l|}{ Normal EEG } & \multicolumn{2}{l|}{ Abnormal EEG } \\
\cline { 2 - 5 } & Total number of patients & $\begin{array}{l}\text { Number of patients with seizures } \\
\text { as a side effect post BMMNCs } \\
\text { transplantation }\end{array}$ & Total Number of patients & $\begin{array}{l}\text { Number of patients with seizures } \\
\text { as a side effect post BMMNCs } \\
\text { transplantation }\end{array}$ \\
\hline $\begin{array}{l}\text { Patients with the history of } \\
\text { seizures and antiepileptic } \\
\text { medication }\end{array}$ & 1 & 0 & 12 & 2 \\
\hline $\begin{array}{l}\text { Patients with history of seizures } \\
\text { without antiepileptic } \\
\text { medication }\end{array}$ & 4 & 0 & 4 & 0 \\
\hline $\begin{array}{l}\text { Patients without any history of } \\
\text { seizures but on antiepileptic } \\
\text { medication }\end{array}$ & 0 & 0 & 4 & 0 \\
\hline
\end{tabular}




\begin{tabular}{|l|l|l|l|l|}
\hline $\begin{array}{l}\text { Patients without any history of } \\
\text { seizures } \text { or antiepileptic } \\
\text { medication }\end{array}$ & 25 & 17 & 0 \\
\hline
\end{tabular}

Table 5: Distribution of patients who underwent prophylactic antiepileptic regimen

\section{Results}

In the prophylactic antiepileptic regimen, 67 patients were included for analysis. None of them had any side effects of the prophylactic antiepileptic regimen. Patients were followed up over a period of eight months. Out of the 67 patients, two showed seizures as an $\mathrm{AE} \mathrm{(3 \% )}$ (Table 5 and Figure 1A).

34 out of these 67 patients had abnormal EEG. 2 out of these 34 had seizures as $\mathrm{AE}$ post transplantation. Percentage incidence of seizures was $6 \%$ for the patients with abnormal EEG (Figure 1B). Both these patients had history of seizures.

None of the patients developed new onset seizures.

None of the patients with normal EEG findings developed seizures as an $\mathrm{AE}$ post transplantation.

It is noteworthy, that in both Part I and Part II, patients who had seizures as an AE did not show any clinical deterioration and it did not interfere with the improvements after cell transplantation.

\section{Comparison of the post transplantation seizure incidence in Part I and Part II}

After administration of prophylactic regimen, the global incidence of seizures as an $\mathrm{AE}$ reduced from $6 \%$ to $3 \%$ and incidence of new onset of seizures reduced from $2 \%$ to $0 \%$ (Figure 1A). For patients with abnormal EEG findings incidence of seizures as an AE reduced from $17 \%$ to $6 \%$ (Figure 1B).

\section{Discussion}

Cellular therapy is a promising new technique for the treatment of pediatric neurological diseases. Efficacy and short term safety of these cells has been demonstrated in various pediatric neurological diseases but the AEs need equal attention [2,5]. The therapeutic benefits are attributed to various paracrine mechanisms more than the actual formation of new neuronal tissue. BMMNCs have been shown to influence the plasticity of endogenous brain cells, modulate the inflammatory response, stimulate neovascularization, prevent apoptosis of host cells and recruit existing stem cells for the repair of damaged tissue [16]. The function of lost neuronal tissue is taken over by the viable neuronal tissue by virtue of cortical reorganization and remapping. This ability of neuronal tissue to adapt their functional potential is termed as plasticity. Brain plasticity is evidenced by increased afferent and efferent connections of the damaged tissue to the surrounding areas, improved synaptic activity and strengthening of current synapses following brain injury $[17,18]$. Cell transplantation increases the expression of synaptic proteins and enhance brain plasticity [19]. BMMNCs have modulatory effect on the inflammatory processes of the brain by alteration of the microglial response [20]. They secrete various anti-inflammatory cytokines like IL-10 responsible for cytoprotection and reduce the levels of inflammatory cytokines like TNF- $\alpha, I L-1 \beta$, IL-1 $\alpha$, IL- 6 . They also induce secretion of neurotrophic factors like connective tissue growth factor, fibroblast growth factor 2 and 7 that are responsible for cell proliferation and neuroprotection [21]. Neurotrophic factors down regulate the cellular apoptotic processes $[20,22]$. Neoangiogenesis triggered by BMMNCs is associated with the magnitude and rate of tissue recovery.[23] There is mobilization and enhanced homing of existing vascular endothelial progenitors from the surrounding areas that are integrated in the repair of the damage to the existing blood vessels [24,25]. Mobilization of stem cells involves the chemoattractant pathways guided by chemokines like stromal derived factor -1 (SDF-1) [26]. These pathways render the cells a unique property to home to the damaged tissue to bring about precise repair. Preexisting epileptogenic focus can also be considered as damaged tissue and similar chemoattractant pathways could bring about the homing of stem cells to these areas. It can be hypothesized that, various paracrine effects as discussed above could lead to increased excitability of these epileptogenic cells triggering a seizure. Neurotrophic factors (NTFs) are fundamentally neuroprotective however they play a dual role in epileptogenesis and may themselves contribute in epileptogenesis. Types of receptors and signaling pathways determine the role of NTFs in epileptogenesis. NTFs comprise of several proteins namely Brain derived neurotrophic factor (BDNF), Nerve growth factor (NGF), basic fibroblast growth factor (FGF-2), Glial cell line derived neurotrophic factor (GDNF) andVascular endothelial growth factor (VEGF). Various proteins from amongst these are found to be proepileptogenic [27]. Kindling models of epileptogenesis in animals suggest FGF-2 and BDNF may be the contributing factors [28]. These models also indicate that VEGF has a pivotal role to play in epileptogenesis post seizures, causing tight junction dysfunction that leads to altered blood brain barrier permeability and increased immunoglobulin $G$ leakage and concentration in neurons [24]. Following seizures, the initial up regulation of VEGF ensures neoangiogenesis, blood flow adaptations and neuroprotection. However excessive angiogenesis leads to upregulation of matrix metalloproteinases; which leads to leakage of albumin in the neurons that increases oncotic pressure and causes interstitial tissue edema, triggerring a new seizure event [25]. NGF has been suggested to have proepileptogenic effect [27]. A seizure episode has also been suggested to increase Monocyte chemoattractant protein -1 which induces migration on neuronal progenitors that may give rise to aberrant circuitry and contribute to epileptogenesis [29]. Theoretically, the increased production of BDNF, VEGF and NGF by BMMNCs transplantation may be implicated as one of the underlying basis for seizure as an AE but the exact mechanism still remains to be unknown.

Children with diagnoses of autism, attention deficit hyperactivity syndrome, rett's syndrome, mental retardation, cerebral palsy or cerebellar ataxia and treated with autologous BMMNCs intrathecal transplantation were analyzed. Epilepsy is found to co-exist in many of these patients [12,13]. Therefore these groups were selectively analyzed. Seizures were considered to be an AE, when there were increased pre-existing seizures or development of new onset seizures. Here we have reported seizure as an AE of cellular therapy for pediatric population. 


\section{Correlation with abnormal EEG}

As reported in the first part out of the 131 children treated, $8(6 \%)$ children developed seizures as an AE post transplantation. Out of these 8 children, 7 showed presence of a pre-existing epileptogenic focus on previous EEG examination. EEG findings were unavailable for one patient who had seizures as an AE. None of the patients with normal EEG had any kind of seizures post cellular therapy. Presence of epileptogenic focus on an EEG either immediate preoperatively or in past could therefore be considered as one of the predictors for seizures as an AE post cellular therapy.

\section{Correlation with history of seizures}

In addition it was observed that out of the 8 patients who had seizures 5 patients had a history of seizures. Animal studies show epileptogenic effects of growth factors are seen only after an initial episode of seizures $[27,30]$. Pre-clinical studies also show that a single episode of febrile seizures is enough to induce epileptogenic changes in an adult brain [30], suggesting long term effects. Such febrile seizures may not necessarily give rise to an epileptogenic focus detectable on EEG. The EEG findings could be normal in such patients but they may still be predisposed to developing seizures. Epileptogenic potential of history of seizures cannot be underestimated. Although this is not sufficient to consider history of seizures as a predicting factor, cautious approach while treating these children is warranted.

\section{Effect of antiepileptic prophylactic regimen}

Based on the findings of part I, we designed an antiepileptic prophylactic regimen (Table 4) for the subsequent patients. Patients showing pre-existing epileptogenic focus on an EEG were given an antiepileptic prophylactic regimen. In addition patients with history of seizures were also considered for the antiepileptic prophylactic regimen. The regimen differed for the patients based on various criteria as explained below. All the patients showing epileptogenic focus on EEG who were not on any antiepileptic medication were treated with a perioperative administration of intravenous levetiracetam as it is safe and tolerable in pediatric population [31]. Oral levetiracetam was continued post operatively for three months. That who had recurrent seizures and was on regular medication, the same medication was continued.

The antiepileptic prophylactic regimen was continued for a maximum of three months because the data in Part I showed that majority of the patients had seizures as an AE in the first three months post BMMNCs transplantation. Also in a study of children with leukemia, autologous and allogenic bone marrow transplantation showed new onset or increased pre-existing seizures in the first three months [13].

Only two (3\%) patients out of 67 showed seizures as an AE of cellular therapy in Part II. Both these patients had a pre-existing epileptogenic focus on EEG, history of seizures and were taking regular antiepileptic medication. The percentage of patients that developed seizures in part II was significantly lesser than part I. None of the patients developed new onset seizures in part II. This suggests that prophylactic antiepileptic regimen can prevent new seizure occurrences post cellular therapy. It is noteworthy that despite seizures as an $\mathrm{AE}$ in both parts I and II, patients showed clinical improvements post BMMNCs transplantation and these improvements were sustained.

\section{Clinical implications}

It is important to understand that increased pre-existing seizures and development of new onset seizures is a potential adverse effect of cellular therapy. In order to prevent and control this AE, detailed clinical information about history of seizure activity, previous EEG examinations, current and previous antiepileptic medication must be acquired. It would be advisable to have pre-existing seizures under control with antiepileptic medications before considering cellular therapy. A pre-procedure EEG examination must be carried out. Prophylactic perioperative antiepileptic medication should be administered to all the patients that demonstrate an abnormal epileptogenic focus on EEG. For patients who have only history of seizures with normal EEG a prophylactic antiepileptic regimen can be considered (Table 4). Any antiepileptic regimen, other than used in this study, may also be tested. Patients should be monitored at regular intervals during the first three months after cellular therapy. Development of new seizures may be prevented completely and increased pre-existing seizures may be controlled with prophylactic antiepileptic medication. The interpretation of these results should take into consideration the limitations of the analysis.

\section{Limitations}

One of the limitations is that exact molecular mechanism for seizures triggered post transplantation was not established and the underlying mechanisms are explained in only theoretical manner. Hence future studies aiming at understanding molecular mechanisms can be undertaken. Here we have reported seizure as an AE of only autologous BMMNCs intrathecal transplantation therefore different cell types and routes of administration should also be studied. This study was conducted only in one center with relatively small sample size which may also be a limitation.

\section{Conclusion}

Although a small percentage of patients show seizures as an AE of autologous BMMNCs intrathecal transplantation, it definitely requires attention. The incidence of seizures reduced from $6 \%$ to $3 \%$ with antiepileptic prophylactic regimen. It is important to understand that it is one of the preventable AEs of cellular therapy in children with neurologic diseases. Pre-existing epileptogenic focus is an independent predictor of the risk of developing seizures as an $\mathrm{AE}$ of cellular therapy. History of seizures and antiepileptic medication should also be considered in assessing the risk. Thorough clinical assessment should be undertaken and prophylaxis, if indicated, should be commenced to prevent this AE. Further analytical studies should consider large sample size, longer follow up duration and multiple centers for conclusive findings.

\section{References}

1. Sanberg PR, Eve DJ, Cruz LE, Borlongan CV (2012) Neurological disorders and the potential role for stem cells as a therapy. Br Med Bull 101: 163-181.

2. Sharma A, Gokulchandran N, Chopra G, Kulkarni P, Lohia M, et al. (2012) Administration of autologous bone marrow-derived mononuclear cells in children with incurable neurological disorders and injury is safe and improves their quality of life. Cell Transplant 2012, 21(Suppl 1):S79S90.

3. Kim SU, de Vellis J (2009) Stem cell-based cell therapy in neurological diseases: a review. J Neurosci Res 87: 2183-2200. 
Citation: Sharma A, Sane H, Paranjape A, Gokulchandran N, Takle M, et al. (2014) Seizures as an Adverse Event of Cellular Therapy in Pediatric Neurological Disorders and its Prevention. J Neurol Disord 2: 164. doi:10.4172/2329-6895.1000164

Page 8 of 8

4. Sharma A, Gokulchandran N, Sane H, Badhe P, Kulkarni P, et al. (2013) Detailed analysis of the clinical effects of cell therapy for thoracolumbar spinal cord injury: an original study. Journal of Neurorestoratology 1: $13-22$.

5. Sharma A, Gokulchandran N, Sane H, Nagrajan A, Paranjape A, et al. (2013) Autologous bone marrow mononuclear cell therapy for autism: an open label proof of concept study. Stem Cells Int 2013: 623875.

6. Deda H, Inci MC, Kürekçi AE, Kayihan K, Ozgün E, et al. (2008) Treatment of chronic spinal cord injured patients with autologous bone marrow-derived hematopoietic stem cell transplantation: 1-year followup. Cytotherapy 2008, 10 (Suppl 6): 565-574.

7. Deda H, Inci MC, Kürekçi AE, Sav A, Kayihan K, et al. (2009) Treatment of amyotrophic lateral sclerosis patients by autologous bone marrowderived hematopoietic stem cell transplantation: a 1-year follow-up. Cytotherapy 11: 18-25.

8. Hentze H, Soong PL, Wang ST, Phillips BW, Putti TC, et al. (2009) Teratoma formation by human embryonic stem cells: evaluation of essential parameters for future safety studies. Stem Cell Res 2: 198-210.

9. Deuse T, Stubbendorff M, Tang-Quan K, Phillips N, Kay MA, et al. (2011) Immunogenicity and immunomodulatory properties of umbilical cord lining mesenchymal stem cells. Cell Transplant 20: 655-667.

10. Antonini G, Ceschin V, Morino S, Fiorelli M, Gragnani F, et al. (1998) Early neurologic complications following allogeneic bone marrow transplant for leukemia: a prospective study. Neurology 50: 1441-1445.

11. Moniche F, Gonzalez A, Gonzalez-Marcos JR, Carmona M, Piñero P, et al. (2012) Intra-arterial bone marrow mononuclear cells in ischemic stroke: a pilot clinical trial. Stroke 43: 2242-2244.

12. Knezevi ̈̈ $\ddagger$-Pogancev M (2010) [Cerebral palsy and epilepsy]. Med Pregl 63: 527-530.

13. Antonini G, Ceschin V, Morino S, Fiorelli M, Gragnani F, et al. (1998) Early neurologic complications following allogeneic bone marrow transplant for leukemia: a prospective study. Neurology 50: 1441-1445.

14. Carlson RV, Boyd KM, Webb DJ (2004) The revision of the Declaration of Helsinki: past, present and future. Br J Clin Pharmacol 57: 695-713.

15. Petit I, Szyper-Kravitz M, Nagler A, Lahav M, Peled A, et al. (2002) GCSF induces stem cell mobilization by decreasing bone marrow SDF-1 and up-regulating CXCR4. Nat Immunol 3: 687-694.

16. Bliss T, Guzman R, Daadi M, Steinberg GK (2007) Cell transplantation therapy for stroke. Stroke 38: 817-826.

17. Bach-y-Rita P (1990) Brain plasticity as a basis for recovery of function in humans. Neuropsychologia 28: 547-554.

18. Corbetta M (2012) Functional connectivity and neurological recovery. Dev Psychobiol 54: 239-253.
19. Shen LH, Li Y, Chen J, Zhang J, Vanguri P, et al. (2006) Intracarotid transplantation of bone marrow stromal cells increases axon-myelin remodeling after stroke. Neuroscience 137: 393-399.

20. Sharma S, Yang B, Strong R, Xi X, Brenneman M, et al. (2010) Bone marrow mononuclear cells protect neurons and modulate microglia in cell culture models of ischemic stroke. J Neurosci Res 88: 2869-2876.

21. Brenneman M, Sharma S, Harting M, Strong R, Cox CS Jr, et al. (2010) Autologous bone marrow mononuclear cells enhance recovery after acute ischemic stroke in young and middle-aged rats. J Cereb Blood Flow Metab 30: 140-149.

22. Gnecchi M, Zhang Z, Ni A, Dzau VJ (2008) Paracrine mechanisms in adult stem cell signaling and therapy. Circ Res 103: 1204-1219.

23. Morin-Brureau M, Rigau V, Lerner-Natoli M (2012) Why and how to target angiogenesis in focal epilepsies. Epilepsia 53 Suppl 6: 64-68.

24. Morin-Brureau M, Lebrun A, Rousset MC, Fagni L, Bockaert J, et al. (2011) Epileptiform activity induces vascular remodeling and zonulaoccludens 1 downregulation in organotypic hippocampal cultures: role of VEGF signaling pathways. J Neurosci 2011, 31(Suppl 29): 10677-10688.

25. Rigau V, Morin M, Rousset MC, de Bock F, Lebrun A, et al. (2007) Angiogenesis is associated with blood-brain barrier permeability in temporal lobe epilepsy. Brain 130: 1942-1956.

26. Borlongan CV, Glover LE, Tajiri N, Kaneko Y, Freeman TB (2011) The great migration of bone marrow-derived stem cells toward the ischemic brain: therapeutic implications for stroke and other neurological disorders. Prog Neurobiol 95: 213-228.

27. Simonato M, Tongiorgi E, Kokaia M (2006) Angels and demons: neurotrophic factors and epilepsy. Trends Pharmacol Sci 27: 631-638.

28. Bregola G, Frigati L, Zucchini S, Simonato M (2000) Different patterns of induction of fibroblast growth factor- 2 and brain-derived neurotrophic factor messenger RNAs during kindling epileptogenesis, and development of a herpes simplex vector for fibroblast growth factor-2 gene transfer in vivo. Epilepsia 41(Suppl 6): S122-S126.

29. Viscidi EW, Triche EW, Pescosolido MF, McLean RL, Joseph RM, et al. (2013) Clinical characteristics of children with autism spectrum disorder and co-occurring epilepsy. PLoS One 8: e67797.

30. Koyama R, Matsuki N (2010) Novel etiological and therapeutic strategies for neurodiseases: mechanisms and consequences of febrile seizures: lessons from animal models. J Pharmacol Sci 113: 14-22.

31. Aceves J, Khan O, Mungall D, Fonkem E, Wright C, et al. (2013) Efficacy and tolerability of intravenous levetiracetam in childrens. Front Neurol 4: 120 . 